\title{
TEKHNIK DAN INSTRUMEN ASSESSMEN RANAH KOGNITIF PESERTA DIDIK DALAM PEMBELAJARAN PAI
}

\author{
Oleh \\ Tamrin $^{160}$ dan Faridathul Munawwarah ${ }^{161}$
}

\begin{abstract}
Abstrak
Teknik dan Instrumen Asssessmen Ranah Kognitif. Yogyakarta: Fakultas Ilmu Tarbiyah dan keguruan Universitas Islam Negeri Sunan Kalijaga Yogyakarta. Makalah ini bertujuan untuk menjelaskan apa saja jenjang atau tingkatan yang ada dalam ranah kognitif, langkah-langkah penyusunan instrumen penilaian ranah kognitif, dan macam-macam teknik yang dapat digunakan dalam penilaian ranah kognitif. Menurut taxonomy bloom Ranah kognitif terdiri dari enam jenjang yaitu, pengetahuan, pemahaman, aplikasi, analisis, sintesis, dan evaluasi. Kemudian, oleh anderson dan krathwohl taxonomy bloom tersebut direvisi sehingga jenjang pengetahuan dibagi menjadi dua dimensi, yaitu dimensi pengetahuan dan dimensi proses kognitif. Dimensi pengetahuan terdiri dari pengetahuan faktual, pengentahuan konseptual, pengetahuan prosedural, dan pengetahuan metakognitif. Dimensi proses kognitif terdiri dari mengingat, memahami, menerapkan, menganalisis, mengevaluasi dan menciptakan. Langkahlangkah penyusunan instrumen penilaian kognitif terdiri dari, penilaian kognitif terdiri dari dua bentuk, yaitu tes dan nontes. Teknik penilaian kognitif dengan tes terdiri item tes pilihan ganda, isian singkat, menjodohkan, benar-salah, dan uraian.
\end{abstract}

Kata kunci: Tekhnik, Instrumen Assessmen Ranah Kognitif, Pembelajaran Pai

\section{Pendahuluan}

Asesmen dalam pembelajaran adalah suatu proses atau upaya untuk memperoleh sejumlah informasi mengenai perkembangan siswa selama kegiatan pembelajaran sebagai bahan dalam pengambilan keputusan oleh guru untuk mengetahui dan memperbaiki proses maupun hasil belajar peserta didik. Dalam konteks pendidikan, pelaksanaan asesmen di sekolah

\footnotetext{
${ }^{160}$ Dosen STIT Dar Aswaja Rokan Hilir Provinsi Riau.

${ }^{161}$ Dosen Tetap Piaud STAI STAI Auliaurrasyidin Tembilahan Kabupaten Indragiri Hilir Provinsi Riau.
} 
merupakan bagian dari proses pembelajaran yakni refleksi pemahaman terhadap perkembangan atau kemajuan siswa secara individual. Tujuan dalam pendidikan dari Taksonomi Bloom telah menjadi salah satu arah dalam pengembangan para guru dalam mencapai suatu proses dan hasil belajar yang diharapkan dapat dicapai peserta didik. terdapat tiga tingkatan Taksonomi Bloom yaitu kognitif, afektif, psikomotorik. Ranah kognitif menjadi aspek yang mayoritas diharapkan dalam pembelajaran.

Salah satu objek atau sasaran evaluasi hasil belajar adalah aspek atau ranah kognitif. Ranah kognitif adalah ranah yang mencakup kegiatan mental. Hasil belajar ranah ini meupakan segala upaya yang meyangkut aktivitas otak. Penilaian juga segala upaya atau tindakan untuk mengetahui sejauh mana tujuan yang telah ditetapkan itu tercapai atau tidak. Dengan kata lain, penilaian berfungsi sebagai alat untuk mengetahui keberhasilan proses dan hasil belajar peserta didik. dalam sistem pendidikan nasional rumusan tujuan pendidikan, baik tujuan kuliner maupun intruksional, menggunakan klasifikasi hasil belalajar. Salah satu prinsip dasar yang harus senantiasa diperhatikan dan dipegangi dalam rangka evaluasi hasil belajar adalah prinsip kebulatan, dengan prinsip evaluator dalam melaksanakan evaluasi hasil belajar dituntut untuk mengevaluasi secara menyeluruh terhadap peserta didik, baik dari segi pemahamannya terhadap materi atau bahan pelajaran yang telah diberikan (aspek kognitif). Dalam penelitian ini yang menjadi rumusan masalah dalam penulisan jurnal ini adalah sebagai berikut: Apa saja jenjang atau tingkat ranah kognitif, Bagaimana langkahlangkah penyusunan instrumen penilaian ranah kognitif, Apa saja teknik yang dapat digunakan dalam penilaian ranah kognitif?

\section{Penilaian Ranah Kognitif}

Asesessmen berasal dari kata assess yang diturunkan dari bahasa latin yaitu assedere, bermakna "duduk disamping”. Dalam konteks pendidikan 
dimaknai bahwa peserta didik duduk disamping seseorang yang membuatnya menentukan tentang apa yang tau atau bisa dilakukan. Secara istilah, penilaian atau asessemen diartikan sebagai sutau kegiatan yang menempatkan siswa dalam sebuah konteks yang menunjukkan atau menjelaskan tentang apa yang bisa dilakukan juga mengenaiapa yang siswa tidak tahu dan tidak mampu lakukan. ${ }^{162}$

Ranah kognitif adalah ranah yang mencakup kegiatan mental (otak). Menurut Bloom, segala upaya yang menyangkut aktivitas otak adalah termasuk dalam ranah kognitif. Dalam ranah kognitif terdapat enam jenjang proses berpikir, mulai dari jenjang terendah sampai dengan jenjang yang paling tinggi. Keenam jenjang yang dimaksud adalah :

1. Pengetahuan (knowledge) adalah kemampuan seseorang untuk mengingat-ingat kembali (recall) atau mengenali kembali tentang nama, istilah, ide, gejala, rumus-rumus dan sebagainya, tanpa mengharapkan kemampuan untuk menggunakannya. Pengetahuan atau ingatan ini adalah merupakan proses berfikir yang paling rendah. Salah satu contohnya hasil belajar kognitif pada jenjang pengetahuan adalah peserta didik dapat menghafal QS. al-'Ashr, menerjemahkan dan menuliskannya secara baik dan benar, sebagai salah satu materi pelajaran kedisplinan yang diberikan oleh guru pendidikan agama Islam di sekolah. ${ }^{163}$

2. Pemahaman (comprehension) adalah kemampuan seseorang dalam mengartikan, menafsirkan, menerjemahkan atau menyatakan sesuatu

${ }^{162}$ Diann Musial, dkk.,Foundation of Meaningfull Educational Assessment, (New York: Mc Grawhill. 2009), h. 3-7.

${ }^{163}$ Anas Sudijono, Pengantar Evaluasi Pendidikan, (Jakarta: PT Raja Grafindo Persada, 2008), h. 49-50 diperkuat oleh Hamzah B.Uno dan Satria Koni, Assessment Pembelajaran, bahwa penilaian kognitif pada jenjang pengetahuan adalah kemampuan seseorang dalam menghafal atau mengingat kembali atau mengulang kembali pengetahuan yang perna diterimanya, (Jakarta: Bumi Aksara, 2013), h. 61. 
dengan caranya sendiri tentang pengetahuan yang pernah diterimanya. ${ }^{164}$ Dengan kata lain, memahami adalah mengetahui tentang sesuatu dan dapat melihatnya dari berbagai segi. Seorang peserta didik dikatakan memahami sesuatu apabila ia dapat memberikan penjelasan atau memberi uraian yang lebih rinci tentang hal itu dengan menggunakan kata-katanya sendiri. Pemahaman merupakan jenjang kemampuan berfikir yang setingkat lebih tinggi dari ingatan atau hafalan. Salah satu contohnya hasil belajar ranah kognitif pada jenjang pemahaman misalnya adalah peserta didik atas pertanyaan guru disuruh menguraikan tentang makna kedisplinan yang terkandungdalam QS. Al-'Ashr secara lancar dan jelas.

3. Penerapan atau aplikasi (application) adalah kesanggupan seseorang untuk menerapkan atau menggunakan ide-ide umum, tata cara ataupun metode-metode, prinsip-prinsip, rumus-rumus, teori-teori dan sebagainya dalam situasi yang baru dan kongkret. Aplikasi atau penerapan ini adalah merupakan proses berfikir setingkat lebih tinggi ketimbang pemahaman. salah satu contoh hasil belajar kognitif jenjang penerapan misalnya adalah peserta didik mampu memikirkan tentang penerapan konsep kedisiplinan yang diajarkan Islamdalam kehidupan sehari-hari, baik lingkungan keluarga, sekolah maupun masyarakat. ${ }^{165}$

4. Analisis (analysis) adalah kemampuan seseorang untuk merinci atau menguraikan suatu bahan atau keadaan menurut bagian-bagian yang lebih kecil dan mampu memahami hubungan di antara bagian-bagian atau faktor-faktor yang satu dengan faktor-faktor yang lainnya. Jenjang analisis adalah setingkat lebih tinggi ketimbang jenjang aplikasi. Contoh

${ }^{164}$ Hamzah B.Uno dan Satria Koni, Assessment Pembelajaran salah satu bagian penting dari pelaksanaan pembelajaran yang tidak dapat diabaikan adalah pelaksaan penilaian, (Jakarta: Bumi Aksara, 2013), h. 61.

${ }^{165}$ Anas Sudijono, Pengantar Evaluasi,....h. 51. 
peserta didik dapat merenung dan memikirkan dengan baik tentang wujud nyata dari kedisplinan seorang siswa di rumah, di sekolah dan dalam kehidupan sehari-hari ditengan-tengah masyarakat, sebagai bagian dari ajaran Islam. ${ }^{166}$

5. Sintesis (synthesis) adalah kemampuan berpikir yang merupakan kebalikan dari proses berpikir analisis. Sintesis merupakan suatu proses yang memadukan bagian-bagian atau undur-unsur secara logis, sehingga menjelma menjadimenjadi suatu pola yang berstruktur atau berbentuk pola baru. Jenjang sintesis kedudukannya setingkat lebih tinggi ketimbang jenjang analisis. ${ }^{167}$ Salah satu contoh hasl belajar kognitif pada jenjang sintesis adalah peserta didik dapat menulis karangan tentang pentingnya kedisplinan sebagaimana telah diajarkan oleh Islam.

6. Penilaian/penghargaan/evaluasi (evaluation) adalah merupakan jenjang berfikir paling tinggi dalam ranah kognitif menurut Taksonomi Bloom. Penilaian atau evaluasi merupakan kemampuan seseorang untuk membuat pertimbangan terhadap situasi, nilai atau ide, misalnya jika seseorang dihadapkan pada beberapa pilihan maka ia mampu memilih satu pilihan yang terbaik sesuai dengan patokan-patokan atau kriteria yang ada. ${ }^{168}$

Keenam jenjang kognitif tersebut bersifat berkesinambungan. Maksudnya, kategori yang paling tinggi mencakup pula kategori yang dibawahnya. Anderson dan krathwohl merevisi aspek kognitif pada taxonomy bloom. Dalam hasil revisi tersebut, Anderson dan Krathwohl membagi aspek kognitif menjadi dua dimensi. Yaitu dimensi pengetahuan dan dimensi proses kognitif.

\footnotetext{
${ }^{166}$ Ibid,. h. 51

${ }^{167}$ Ibid,. h. 52 .

${ }^{168}$ Ibid,. h. 52 .
} 


\section{Dimensi proses kognitif}

Dimensi proses kognitif menunjukkan keterampilan berpikir yang hendak dikembangkan dalam kegiatan pembelajaran. Keterampilan berpikir diformulasikan menjadi enam kategori, setiap kategori memiliki kata kerja operasional (KKO). Dimensi ini mencakup kemampuan mengingat, mengerti/memahami, menerapkan, menganalisis, mengevaluasi, dan menciptakan. ${ }^{169}$

\section{Dimensi pengetahuan}

Dimensi pengetahuan terdiri dari: ${ }^{170}$

a. Pengetahuan faktual: pengetahuan tentang fakta-fakta, istilah, dan rincian dari suatu materi.

b. Pengetahuan konseptual: pengetahuan tentang cara bahwa ide/gagasan dapat diklasifikasikan, dikategorikan, atau dikembangkan menjadi prinsip, model, atau teori.

c. Pengetahuan prosedural: pengetahuan tentang proses atau prosedur dalam melakukan suatu kegiatan.

\section{Langkah-langkah Penyusunan Tehnik dan Instrumen Asessmen pada Ranah Kognitif}

Salah satu tehnik evaluasi hasil belajar kognitif adalah tes verbal yang berwujud butir-butir soal. Secara umum, ada beberapa langkah yang harus ditempuh dalam penyusunan instrument tes verbal, yaitu (1) menentukan tujuan dan kawasan tes, (2) menguraikan materi dan batasan perilaku yang akan di ukur, (3) menyusun kisi-kisi, (4), memilih bentuk tes, (5) menentukan panjang tes, (6) menulis soal coba tes, (7) menelaah soal tes,

${ }^{169}$ Herman Y.S. Endrayanto dan Yustiana W. Harumurti, Penilaian Belajar Siswa di Sekolah, (Yogyakarta: Kanisius, 2014), h. 35.

${ }^{170}$ Ibid., h. 37-39. 
(8) melakukan uji coba tes, (9) menganalisis butir soal, (10) memperbaiki tes dan (11) merakit tes. Yang akan dikaji satu persatu sebagau berikut:

Pertama, Menentukan tujuan dan kawasan tes. Perumusan tujuan tes dapat mengacu kepada fungsi tes yang disusun yaitu apakah fungsi formatif, fungsi sumatif atau fungsi diagnostik.Masing masing tujuan evaluasi menghendaki adanya penyesuaian dalam tes yang direncanakan.Fungsi formatif adalah untuk mengukur tingkat penguasaan peserta didik.Sedangkan fungsi sumatif adalah untuk penentuan nilai akhir dalam suatu program, penentuan taraf penguasaan, penentuan kelulusan.Dan fungsi diagnostik adalah untuk mengetahui kesulitan-kesulitan belajar yang dihadapi peserta didik atau mendeteksi kesukaran belajar dan sebabsebabnya. ${ }^{171}$

Kedua, Menguraikan materi tes dan kompetensi. Mengurakan materi atau isi (delination of content) pelajaran yang akan diujikan berpedoman pada prinsip "memasukkan sesuatu yang masuk dan mengeluarkan sesuatu yang harusnya keluar". Maksudnya, bahwa penguraian isi tes bukan saja berarti mengusahakan agar tes yang akan ditulis itu tidak keluar dari lingkup materi yang telah ditentukan oleh batasan kawasan ukur akan tetapi berarti pula mengusahakan agar jangan sampai ada bagian isi yang penting yang terlewatkan dan tidak tertuang dalam tes. ${ }^{172}$

${ }^{171}$ Sukiman, Pengembangan Sistem Evaluasi, (Yogyakarta: Insan Madani, 2011), h. 80 diperkuat oleh Ngalim Purwanto di dalam bukunya yang berjudul Prinsip-prinsip dan Tehnik Evaluasi Pengajaran, bahwa fungsi penilaian formatif yang bertujuan untuk mencari umpan balik, dan fungsi sumatif untuk memperoleh data dan informasi sampai dimana penguasaan atau pencapaian belajar siswa terhadap bahan pelajaran yang telah dipelajarinya selama jangka waktu tertentu. sedangkan fungsi daignostik berfungsi untuk membantu memecahkan kesulitan belahar siswa. (Bandung: CV Remadja Karya, 1988), h.35

${ }^{172}$ Wayan Nukancana \& Sumartana, Evaluasi Pendidikan Cet III, (Surabaya: Usaha Nasional, 1983), h.130. 
Ketiga, menyusun kisi-kisites.Kisi-kisi tes atau blue print (Cetak biru) adalah deskripsi mengenai ruang lingkup materi dan aspek kompetensi yang akan diujikan yang umumnya dituangkan dalam sebuah matriks. Ada dua bentuk kisi-kisi yang perlu dibuat oleh penyusun tes, yaitu a) kisi-kisi untuk menentukan proporsial materi dan kompetensi yang diujikan dan b) kisi-kisi untuk menentukan bentuk soal yang sesuai dengan muatan materi. Dan langkah-langkah penyusunan kisi-kisi untuk menetukan proporsi materi dan kompetensi adalah sebagai berikut:

a. Mengidentifikasi pokok-pokok materi yang akan diujikan dengan memberikan imbangan bobot untuk masing-masing bahasan,

b. Mengidentifikasi tindakan ranah kognitif yang termuat dalam rumusan indikator dan memberikan imbangan bobot masing-masing tingkatan ranah. Dan pencapaian tingkatan ranah kognitif hendaknya disesuaikan dengan jenjang pendidikan. Contoh untuk mata pelajaran PAI di SMP:

Ranah Kognitif Bobot

Pengetahuan (20\%)

Pemahaman $\quad(30 \%)$

Aplikasi $\quad(30 \%)$

Analisa $\quad(20 \%)$

Sintesa $\quad(0 \%)$

Evaluasi $\quad(0 \%)$

c. Memasukkan ranah dan pokok-pokok materi yang telah teridentifikasi ke dalem table spesifikasi.

d. Memerinci banyaknya butir soal dalam setiap pokok materi dan ranah yang akan dicapai. ${ }^{173}$

Keempat, Pemilihan bentuk tes. Pemilihan bentuk tes yang tepat didasarkan pada beberapa faktor seperti tujuan tes, jumlah peserta tes, waktu

${ }^{173}$ Sukiman, Pengembangan Sistem Evaluasi,....h. 82-83.

128 
yang tersedia untuk memeriksa lembar jawaban tes, cakupan materi tes dan karakteristik mata pelajaran yang diujikan. Bentuk tes objektif pilihan ganda, menjodohkan isian dan bentuk benar salah tepat digunakan bila jumlah peserta tess banyak, waktukoreksi singkat dan cakupan materi yang diujikan banyak. ${ }^{174}$

Kelima, menentukan panjang tes. Panjang tes yang dimaksud adalah jumlah soal yang ini ditentukan oleh waktu yang tersedia untuk melakukan ujian dengan memerhatikan bahan yang diujikan dan tingkat kelelahan peserta tes. Ada tiga hal utama yang harus dipertimbangkan dalam menentukan jumlah soal yang diujikan, yaitu:

a. Bobot Masing-Masing Bagian Yang Telah Ditentukan Dalam Kisi-Kisi.

b. Keandalan Yang Diinginkan Dan

c. Waktu yang tersedia.

Bobot skor tiap soal bisa ditentukan sebelum tes digunakan, yaitu berdasar tingkat kompleksitas atau kesulitannya yang kompleks atau sulit diberi bobot lebih tinggi dibandingkan dengan yang lebih mudah. ${ }^{175}$

Keenam, menulis soal. Untuk menuliskan soal-soal tes yang baik, maka kita harus berpedoman kepada saran-saran penyusunan soal untuk tiap-tiap tipe tes.Banyak tes yang ditulis hendaknya lebih banyak dari pada soal yang diperlukan, sehingga nantinya bisa dipilih soal-soal mana yang lebih baik. ${ }^{176}$

\section{Teknik Penilaian Ranah kognitif}

Ada dua teknik penilaian ranah kognitif, yaitu teknik tes dan non tes. Tes untuk evaluasi hasil belajar kognitif, dari segi caranya dapat dibedakan menjadi dua macam, yaitu tes lisan dan tes tertulis. Sedangkan dari segi

${ }^{174}$ Muri Yusuf, Asesmen dan Evaluasi Pendidikan Pilar Penyedia Informasi dan Kegiatan Pengendalian Mutu Pendidikan, (Jakarta: Prenadamedia Group, 2015), h. 181.

175 Sukiman, Pengembangan Sistem Evaluasi,.... h.86.

${ }^{176}$ Wayan Nukancana \& Sumartana, Evaluasi,...h. 54. 
bentuknya, tes dibedakan menjadi dua macam pula yaitu tes objektif dan tes subjektif (uraian). Tes objektif terdiri dari beberapa bentuk, yaitu tes model pilihan ganda, tes isian singkat, tes menjodohkan, tes benar-salah. Tes subjektif (uraian) ada dua bentuk, yaitu tes uraian terbatas dan tes uraian bebas. ${ }^{177}$

1. Pilihan ganda

Item tes pilihan ganda merupakan jenis tes objektif yang sering digunakan oleh pendidik. Tes ini dapat mengukur pengetahuan yang luas dan domain yang bervariasi. Item tes pilihan ganda memiliki semua persyaratan sebagai tes yang baik, yakni dilihat dari segi objektivitas, reliabilitas, dan daya pembeda antar siswa. ${ }^{178}$

Kelebihan tes pilihan ganda: ${ }^{179}$

a. Memiliki karakteristik yang baik untuk suatu alat pengukur hasil belajar siswa. Karakteristik yang baik tersebut yaitu lebih fleksibel dalam implementasi evaluasi dan efektif untuk mengukur tercapai tidaknya tujuan pembelajaran.

b. Dapat mencakup hampir seluruh bahan pembelajaran yang disampaikan guru dikelas.

c. Tepat untuk mengukur penguasaan informasi para siswa yang hendak dievaluasi.

d. Jawaban siswa dapat dikoreksi dengan mudah.

e. Hasil jawaban dapat dikoreksi bersama oleh siswa dan guru. ${ }^{180}$

f. Dapat mengukur berbagai jenjang kognitif.

g. Reliabilitas soal pilihan ganda lebih tinggi dibanding dengan soal uraian. ${ }^{181}$

${ }^{177}$ Sukiman, Pengembangan Evaluasi Sistem..., h. 77.

${ }^{178}$ Sukardi, Evaluasi Pendidikan Prinsip dan Modelnya, (Jakarta: Bumi Aksara, 2008), h. 125.

${ }^{179}$ Ibid.,

${ }^{180}$ Ibid., 
Kekurangan tes pilihan ganda ${ }^{182}$

a. Konstruksi item tes pilihan ganda lebih sulit serta membutuhkan waktu yang lama. Seperti kesulitan dalam menyusun item tes yang mengandung pokok persoalan dengan tepat, dan menyusun alternatif jawaban penjebak yang baik.

b. Kurang dapat mengukur kecakapan siswa dalam mengorganisasi materi hasil pembelajaran.

c. Memberi peluang pada siswa untuk menerka jawaban.

d. Tidak cocok digunakan untuk mengukur kemampuan problem solving. ${ }^{183}$

Ada beberapa model tes pilihan ganda yang dapat digunakan dalam evaluasi hasil belajar PAI, yaitu: ${ }^{184}$

a. Model pilihan ganda biasa

Yaitu model pilihan ganda yang terdiri dari kalimat pertanyaan atau pernyataan dan diikuti oleh 3,4 , atau 5 jawaban.

b. Model asosiasi

Model pilihan ganda yang terdiri dari 4 atau 5 pilihan, kemudian diikuti beberapa kalimat pertanyaan atau pernyataan dan tugas siswa adalah memilih pasangan jawaban yang paling tepat.

c. Model melengkapi berganda

Model pilihan ganda yang terdiri dari kalimat pertanyaan atau pernyataan dan diikuti oleh beberapa alternatif jawaban, dimana jawaban yang benar bisa lebih dari satu.

d. Model analisis hubungan antarhal

${ }^{181}$ Sukiman, Pengembangan Evaluasi Sistem..., h. 89-90.

${ }^{182}$ Sukardi, Evaluasi Pendidikan Prinsip dan Modelnya...., h. 126.

${ }^{183}$ Sukiman, Pengembangan Evaluasi Sistem..., h. 90.

${ }^{184}$ Ibid., h. 90-98. 
Yaitu soal model pilihan ganda yang terdiri dari atas kalimat pertanyaan dan diikuti oleh satu kalimat keterangan/alasan. Testee diminta menganalisis kebenaran dan hubungan kedua kalimat tersebut.

e. Model

Model soal ini berangkat dari sebuah kasus baik bersifat kasus buatan (fiktif) ataupun kasus yang sesungguhnya terjadi dimasayarakat. Dari kasus tersebut kemudian kepada peserta ujian diajukan satu atau beberapa pertanyaan terkait dengan kasus tersebut.

f. Model pemakaian diagram, grafik, peta, atau gambar.

Model pilihan ganda ini biasanya alternatif jawaban itu dimunculkan dalam diagram, grafik, peta, atau gambar dengan menggunakan tanda huruf. Kemudian kepada peserta ujian ditanyakan tentang sifat/keadaan/ hal-hal tertentu yang berhubungan dengan tanda-tanda tersebut.

Hal-hal yang harus diperhatikan dalam tes pilihan ganda:

a. Instruksi pengerjaannya harus jelas dan bila dipandang perlu baik disertai contohnya.

b. Hanya ada satu jawaban benar

c. Hendaknya kalimat pokok mencakup dan sesuai dengan rangkaian manapun yang dapat dipilih

d. Kalimat pada tiap butir soal hendaknya sesingkat mungkin.

e. Usahakan menghindari penggunaan bentuk negatif dalam kalimat pokoknya. ${ }^{185}$

f. Pokok soal harus ditulis lengkap, menggambarkan pilihan jawaban dan seluruh pengecoh yang disajikan.

${ }^{185}$ Sudaryono, Dasar-Dasar Evaluasi Pembelajaran, (Yogyakarta: Graha Ilmu, 
g. Setiap pilihan jawaban menggunakan struktur bahasa atau kalimat yang konsisten (sama panjang atau pendeknya)

h. Tidak mencantumkan pilihan jawaban "semua jawaban diatas benar" atau "semua pilihan jawaban diatas salah".

i. Pilihan jawaban yang berbentuk angka atau waktu diurutkan berdasarkan besar kecil nya angka atau urutan kronologisnya. ${ }^{186}$

2. Isian singkat

Tes jawaban singkat atau isian singkat adalah bentuk tes yang berupa kalimat pertanyaan yang harus dijawab dengan jawaban singkat atau kalimat perintah yang harus dikerjakan atau kalimat pernyataan yang belum selesai sehingga testee harus mengisikan kata untuk melengkapi kalimat tersebut. Bentuk tes ini tepat digunakan untuk mengetahui tingkat ingatan atau hafalan dan pemahaman peserta didik. Tes ini juga dapat memuat materi dalam jumlah materi yang banyak, namun tingkat berpikir yang diukur cenderung rendah. ${ }^{187}$

\section{Menjodohkan}

Soal menjodohkan atau biasa disebut dengan matching test item adalah bentuk soal yang terdiri dari dua kelompok pernyataan. Kelompok pertama merupakan stimulus atau permis yang berupa kalimat diletakkan pada lajur sebelah kiri. Kelompok kedua merupakan respon atau jawaban dari kelompok pertama dan ditulis pada lajur kanan. ${ }^{188}$ Jenis soal menjodohkan dapat mengukur kemampuan siswa menganalisis hubungan antar kata, istilah, definisi, peristiwa, atau kategori tertentu. Bentuk soal

\footnotetext{
${ }^{186}$ Herman Y.S. Endrayanto dan Yustiana W. Harumurti, Penilaian Belajar ..., h.
} 87-89.

\footnotetext{
${ }^{187}$ Sukiman, Pengembangan Evaluasi Sistem..., h. 99.

${ }^{188}$ Sudaryono, Dasar-Dasar Evaluasi Pembelajaran..., h. 115.
} 
menjodohkan dapat digunakan untuk mengukur kemampuan pada kategori mengingat, memahami/mengerti, dan menganalisis. 189

Kelebihan item tes menjodohkan: ${ }^{190}$

a. Luasnya materi yang dapat dicakup

b. Relatif lebih mudah dibuat butir soal, khususnya jika dibandingkan dengan soal bentuk pilihan ganda.

c. Ringkas dan ekonomis dilihat dari segi cara memberikan jawaban

d. Dapat dilakukan dengancepat dan mudah dalam penskorannya.

Sedangkan kelemahannya adalah sebagai berikut: ${ }^{191}$

a. Cenderung untuk mengukur kemampuan mengingat. Kurang tepat digunakan untuk mengukur kemampuan yang lebih tinggi.

b. Sukarnya menjaga kehomogenan isi premis dan respon.

c. Kemungkinan menebak dengan benar relatif lebih tinggi.

4. Tes benar-salah

Item tes benar-salah berupa pernyataan-pernyataan. Pernyataan tersebut ada yang benar dan salah. Tugas siswa adalah menandai pernyataan tersebut benar atau salah. Bentuk soal benar-salah terbatas untuk mengukur kemampuan mengidentifikasi informasi berdasarkan hubungan yang sederhana. ${ }^{192}$

Bentuk benar-salah ada dua macam, yaitu dengan pembetulan, apabila siswa diminta membetulkan pernyataan yang salah dan tanpa pembetulan jika siswa hanya diminta untuk melingkari atau memilih B atau S. ${ }^{193}$

${ }^{189}$ Herman Y.S. Endrayanto dan Yustiana W. Harumurti, Penilaian Belajar ..., h. 90.

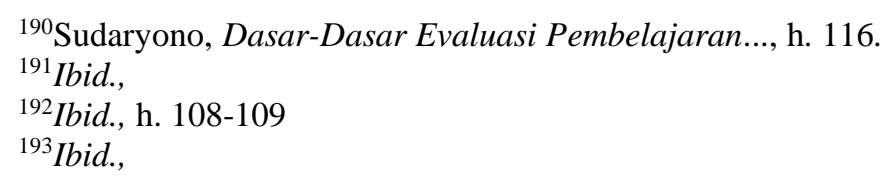


Kelebihan tes benar-salah: ${ }^{194}$

a. Dapat mencakup bahan yang luas dan tidak memakan banyak tempat

b. Mudah menyusunnya

c. Dapat digunakan berkali-kali

d. Dapat dilihat secara cepat dan objektif

e. Petunjuk cara mengerjakannya mudah dan objektif.

$$
\text { Kekurangan: }{ }^{195}
$$

a. Sering membingungkan

b. Mudah ditebak

c. Banyak masalah yang tidak dapat dinyatakan hanya dengan dua kemungkinan benar/salah.

d. Hanya mengungkap daya ingatan dan daya pengenalan kembali.

e. Terbatas pada kemampuan pengetahuan saja.

f. Tingkat reliabilitas dan validitasnya rendah.

\section{Uraian}

Tes esai lebih banyak digunakan untuk mengukur kemampuan yang lebih tinggi dalam kawasan kognitif, seperti menggunakan, menganalisis, menilai dan berpikir kreatif. Sebab melalui tes tipe ini siswa diajak untuk dapat menerangkan, mengungkapkan, menciptakan, membandingkan, maupun menilai suatu objek evaluasi. Tes uraian menyediakan kebebasan kepada peserta didik dalam menentukan responnya terhadap materi yang ditanyakan. ${ }^{196}$ (Muri Yusuf, hal. 207)

Tes uraian dapat dibedakan dalam dua bentuk, yaitu: ${ }^{197}$
a. Tes uraian bebas
b. Tes uraian tersturuktur

\section{${ }^{194}$ Ibid.,}

${ }^{195}$ Ibid.,

${ }^{196}$ A. Muri Yusuf, Asesmen dan Evaluasi Pendidikan, (Jakarta: Kencana, 2015), h. 207 .

${ }^{197}$ Ibid., h. 208. 
Kelebihan tes uraian adalah: ${ }^{198}$

a. Pendidik mudah menyusun pertanyaan yang diberikan

b. Menghemat waktu dalam menyusun pertanyaan

c. Mampu mengukur kawasan kognitif yang lebih tinggi

d. Tidak membutuhkan fasilitas yang banyak.

Kekurangan tes uraian adalah: ${ }^{199}$

a. Sering disertai unsur-unsur subjektif dalam penilaian

b. Kurangnya kemampuan peserta didik dalam isi suatu butir soal.

c. Jawaban yang mudah dibaca, sering dihargai lebih tinggi nilainya dari jawaban yang sukar dibaca.

d. Tidak dapat mewakili semua bahan yang diajarkan.

e. Membutuhkan waktu yang lama dalam menskor.

Kemudian untuk teknik non tes, ada beberapa teknik non tes yang dapat digunakan untuk mengevaluasi hasil belajar kognitif yaitu portofolio, proyek (penugasan), dan produk. Teknik non tes ini sifatnya untuk melengkapi teknik tes. ${ }^{200}$

\section{Portofolio}

Penilaian berbasis portofolio ini dilaksanakan dengan cara "mengumpulkan secara terencana berbagai hasil karya atau rekaman tingkah laku yang bersama-sama memberikan gambaran komprehensif tentang pencapaian seseorang dalam suatu keahlian”. Artinya, portofolio merupakan sebuah kumpulan terencana dari murid yang mampu mengisahkan tentang usaha, kemajuan, atau prestasi murid dalam bidang pelajaran atau keahlian tertentu. ${ }^{201}$

\section{${ }^{198}$ Ibid.,}

${ }^{199}$ Ibid.,

${ }^{200}$ Sukiman, Pengembangan Evaluasi Sistem..., h. 109.

${ }^{201}$ A. Supratiknya, Penilaian Hasil Belajar dengan Non tes, (Yogyakarta: Sanata Dharma, 2012), h. 57.

\section{6}


2. Penilaian Proyek (penugasan)

Penilaian proyek adalah penilaian pada kemampuan melakukan "scientific inquiry" yang dapat memberikan informasi tentang kemampuan peserta didik mengaplikasikan pengetahuan dalam merencanakan, mengorganisasi penyelidikan, kerja sama, mengidentifikasi, mengumpulkan informasi, menganalisis dan menginterpretasikan serta mengkomunikasikan temuannya dalam bentuk laporan tulisan. ${ }^{202}$

\section{Penilaian Produk}

Penilaian terhadap hasil artikel atau benda yang dihasilkan peserta didik dalam periode tertentu. ${ }^{203}$

\section{Problematikan Perkembangan Kognitif Peserta didik}

a. Masa kanak-kanak

Permasalahan membaca pada masa ini masih dengan cara dieja, pemahamannya hanya satu kata dan terkadang anak sulit diajak belajar membaca. Solusi: membaca diikuti kata-kata bergambar agar menari anak untuk membaca.

b. Masa kanak-kanak akhir

Permasalah membaca dan pemahaman di SD saat ini umumnya menggunakan sistem klasikal yang menempatkan kecepatan memahami isi bacaan berdasarkan kecepatan rata-rata memahami isi buku atau siswa merasa bahwa pembelajaran membaca pemahaman yang dilakukan oleh guru terlalu cepat.

Solusi: guru mengefektifkan dengan mengelompokkan siswa menjadi 8 kelompok dengan memahami isi bacaan dan sharing

\footnotetext{
${ }^{202}$ Sukiman, Pengembangan Evaluasi Sistem..., h. 117.

${ }^{203}$ Ibid., h. 118.
} 
c. Masa Remaja

Permasalahan membaca pemahaman di masa SMP/SMA lebih ke kurang memahmi isi bacaan.

\section{Kesimpulan}

Konsep penilaian atau asessmen adalah satu paket dengan beberapa istilah yang berdekatan maknanya, seperti tes, ujian, evaluasi dan sebagainya. Walaupun istilah tersebut saling berkaitan namun, istilah-istilah tersebut memiliki perbedaan. Asesessmen berasal dari kata assess yang diturunkan dari bahasa latin yaitu assedere, bermakna "duduk disamping”. Secara istilah, penilaian atau asessemen diartikan sebagai sutau kegiatan yang menempatkan siswa dalam sebuah konteks yang menunjukkan atau menjelaskan tentang apa yang bisa dilakukan juga mengenaiapa yang siswa tidak tahu dan tidak mampu lakukan. Ranah kognitif adalah ranah yang mencakup kegiatan mental. Hasil belajar ranah ini meupakan segala upaya yang meyangkut aktivitas otak. Penilaian juga segala upaya atau tindakan untuk mengetahui sejauh mana tujuan yang telah ditetapkan itu tercapai atau tidak. Dengan kata lain, penilaian berfungsi sebagai alat untuk mengetahui keberhasilan proses dan hasil belajar peserta didik.

Kehnik evaluasi hasil belajar kognitif adalah tes verbal yang berwujud butir-butir soal. Secara umum, ada beberapa langkah yang harus ditempuh dalam penyusunan instrument tes verbal, yaitu (1) menentukan tujuan dan kawasan tes, (2) menguraikan materi dan batasan perilaku yang akan di ukur, (3) menyusun kisi-kisi, (4), memilih bentuk tes.

\section{Referensi}

Diann Musial, dkk.,Foundation of Meaningfull Educational Assessment, New York: Mc Grawhill.

Endrayanto, Herman Y.S. dan Yustiana W. Harumurti, Penilaian Belajar Siswa di Sekolah, Yogyakarta: Kanisius, 2014.

\section{8}


Nukancana, Wayan \& Sumartana, Evaluasi Pendidikan Cet III,Surabaya: Usaha Nasional, 1983.

Sudaryono, Dasar-Dasar Evaluasi Pembelajaran, Yogyakarta: Graha Ilmu, 2012.

Sudijono, Anas, Pengantar Evaluasi Pendidikan,Jakarta: PT Raja Grafindo Persada, 2008.

Sukardi, Evaluasi Pendidikan Prinsip dan Modelnya,Jakarta: Bumi Aksara, 2008.

Suharsimi Arikunto, Dasar-dasar Evaluasi Pendidikan,Jakarta: Bina Aksara, 1989.

Sukiman, Pengembangan Sistem Evaluasi, Yogyakarta: Insan Madani, 2011.

Supratiknya, A., Penilaian Hasil Belajar dengan Non tes, Yogyakarta: Sanata Dharma, 2012.

Uno, Hamzah B. dan Satria Koni, Assessment Pembelajaran salah satu bagian penting dari pelaksanaan pembelajaran yang tidak dapat diabaikan adalah pelaksaan penilaian, Jakarta: Bumi Aksara, 2013. 